

\section{Biochemical aspects}

Melanin pigments can be roughly classified into those giving dark colours, namely black and brown and their derivatives, and those giving light ones, with a wide range from the bright yellow coat of some mice to the carroty red colour of some human hair. The dark colours are regarded as deriving from a fairly homogeneous group of insoluble nitrogenous pigments, the eumelanins, which are irregular polymers consisting mainly of 5,6-dihydroxyindole units at various oxidative levels (Nicolaus, I968). The light colours are usually described under the omnibus term of "phaeomelanins", but these include pigments with diverse chemical and physical properties. The best characterized group of these phaeomelanins is found in reddish human hair and in feathers and contains sulphur in addition to nitrogen (ProTA, I972). Degradative studies (FATTORUsso et al., I970) arried out on various pigments of this group isolated from hair of rabbits, sheep, and from red human hair, suggest that the building units which constitute these complex macromolecules are formed by benzothiazole, I,4-benzothiazine and tetrahydroisoquinoline systems, thus being chemically quite different from eumelanins. Another group of phaeomelanic pigments consists of the trichochromes (PROTA and Thomson, I976), formerly named trichosiderins because thought to contain iron. These compounds of low molecular weight occur in certain types of yellow and reddish human hair and are the only "melanin " pigments with a well-defined structure, characterized by a novel nitrogen and sulphur containing chromophore

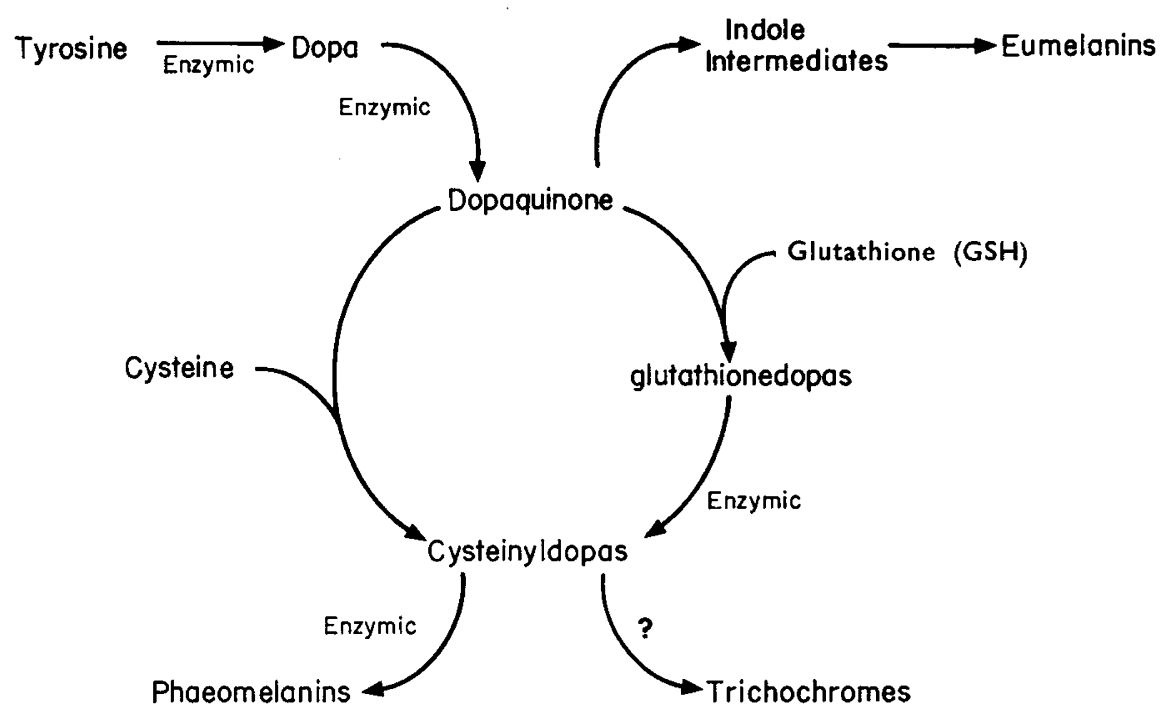

FIG. I. - Tentative scheme of the probable metabolic pathways leading to formation of the different kinds of melanin pigment. "Phaeomelanins" refers to the complex phaeomelanin pigments as distinct from the simpler trichochromes.

Schéma possible des voies métaboliques qui conduisent à la formation des différents types de pigments mélaniques. Par phaeomelanines on désigne les pigments phaeomélaniques complexes qui se distingue des trichochromes plus simples. 
consisting of two conjugated r,4-benzothiazine units. Despite their evident differences in molecular size and general properties, it is now well established that eumelanins, complex phaeomelanins, and trichochromes are biogenetically related, arising from a common metabolic pathway (fig. I) in which dopaquinone is the key intermediate.

In the melanocytes of dark-coloured forms dopaquinone is converted into eumelanin by a complex series of spontaneous reactions which involve cyclization and oxidative polymerization. However, a switch mechanism exists which leads to the production of the S-containing phaeomelanins instead, through the intervention of sulphydryl compounds such as glutathione and/or cysteine. This latter combines with dopaquinone in a non-enzymic very fast reaction to give the cysteinyldopas which, by further oxidation, are converted into phaeomelanins and/or trichochromes. It is not yet clear whether the cysteinyldopas required for phaeomelanin formation are derived by $(i)$ direct addition of free cysteine to dopaquinone or $(i i)$ by reaction of the latter with glutathione, followed by enzymic hydrolysis of the resultant glutathionedopa, or (iii) by both mechanisms. In this context, it is noteworthy that both cysteinyldopa (BIORKLUND et al., I972) and glutathionedopa (AGRUP et al., I975) occur in melanoma tissues which seem to contain also the hydrolytic enzymes ( $\gamma$-glutamyl transferase and a peptidase) capable of converting the latter into the former.

The same phenolase complex, known as tyrosinase (s), is thought to catalyse the conversion of tyrosine to dopaquinone in each of the pathways. Once formed, the subsequent fate of dopaquinone is the result of its own reactivity coupled with the chemical environment within the melanocyte, which is under genetic control. While the formation of eumelanin from this intermediate compound does not require any specific enzymic assistance, the formation of the S-containing phaeomelanins via cysteinyldopa requires at least an additional enzymic control of the concentration of cysteine (or glutathione) in the melanocyte. In vitro biosynthetic experiments (FATTORUSSo et al., I969) suggest that the subsequent conversion of cysteinyldopa to the pigmentary end-products may again be mediated by the tyrosinase complex in the presence of dopa as co-factor. However, an additional enzyme may be needed for trichochrome production.

Thus biochemical information suggests that for the formation of eumelanins from tyrosine at least one enzyme, and therefore one gene locus, is required while for the formation of the complex phaeomelanins or trichochromes from tyrosine at least two enzymes and two loci are needed. In formation of the melanosomes or pigment granules the melanins are laid down on a protein framework; for the formation of this framework other enzymes may be needed. It is interesting to note that the organization and shape of the phaeomelanosomes are different from that of the eumelanosomes (Moyer, I966).

\section{Genetic aspects}

Six main series of multiple alleles $(A, B, C, D, E, P)$ concerned with coat colour are known to be widely distributed in mammals while a number of other possibly homologous loci have been described (SEARLE, I968). In addition, genetic studies on the mouse and other mammals have revealed many loci affecting coat colour for which no homologies have yet been postulated. Table I lists the main allelic 
TABLE I

Characteristics of the main allelic series determining coat colour in mammals

Caractéristiques des principales séries alléliques déterminant la couleur du pelage des mammifères

\begin{tabular}{|c|c|c|c|c|c|}
\hline Series & & Name & Main alleles & Effects and mode of action & Site of action \\
\hline Albino . & . . & C & $C^{+}, c^{c h}, c^{h}, c$ & $\begin{array}{l}\text { Reduces intensity of pig- } \\
\text { mentation, first yellow } \\
\text { and then black, until none } \\
\text { is left in } c c \text { (albino). }\end{array}$ & Within melanocyte \\
\hline Agouti . & . . & $A$ & $A^{y}, A^{w}, A^{+}, a^{t}, a, a^{e}$ & $\begin{array}{l}\text { Controls regional distribu- } \\
\text { tion of black and yellow } \\
\text { pigments in body and in } \\
\text { individual hairs, from all } \\
\text { yellow (dominant in mou- } \\
\text { se) to all black. }\end{array}$ & Outside melanocyte \\
\hline Extension & & $E$ & $E^{d}, E+, e^{b r}, e$ & $\begin{array}{l}\text { Extends black (dominant) or } \\
\text { yellow (recessive) pigment } \\
\text { in body as a whole, with } \\
e^{\text {br giving a black/yellow }} \\
\text { variegation. }\end{array}$ & Within melanocyte \\
\hline Brown . & . . & $B$ & $B^{l t}, B^{+}, b$ & $\begin{array}{l}\text { Affects eumelanins, chang- } \\
\text { ing black to brown in } b b \text {. } \\
\text { May lighten eyes }(b b) \text { and } \\
\text { under-fur }\left(B^{t t}\right) \text {. }\end{array}$ & Within melanocyte \\
\hline Dilute . & . . & $D$ & $D^{+}, d, d^{l}$ & $\begin{array}{l}\text { Dilutes both black and yel- } \\
\text { low colours by clumping } \\
\text { pigment granules. Dilute } \\
\text { lethals }\left(d^{l}\right) \text { have convul- } \\
\text { sions. }\end{array}$ & $\begin{array}{l}\text { Within melanocyte, } \\
\text { changing shape }\end{array}$ \\
\hline Pink-eyed & & $P$ & $P^{+}, p, p^{s}$ & $\begin{array}{l}\text { Main effect on eumelanoso- } \\
\text { mes, with dark colours } \\
\text { much more diluted than } \\
\text { light ones. Retinal pig- } \\
\text { mentation removed in } p \\
\text { and } p^{s} p^{s} \text { also causes } \\
\text { male sterility. }\end{array}$ & Within melanocyte \\
\hline
\end{tabular}

series, with what is known about the mode of action of the genes concerned. Since genes affecting trichochromes have not yet been studied in experimental mammals these pigments will be included under phaeomelanins in the remarks which follow.

\section{Albino}

This is thought to be the structural locus for tyrosinase (FOSTER, I965), since the bottom recessive $(c)$ leads to absence of all melanin, while intermediate alleles reduce the amounts of yellow and dark pigments. The effect on yellow pigment 
is more pronounced. The belief that this is a structural rather than a regulatory gene is strengthened by the identification of a " himalayan " or acromelanistic allele in a number of species, in which the amount of pigmentation depends on skin température (see SEARLE, I968). Thus this mutant allele presumably controls the formation of a different, thermolabile, form of the tyrosinase enzyme. HEARING (1973), however, reported a low level of tyrosinase activity in albino mice and suggested that the $c$ locus is a regulator rather than a structural one.

It should be pointed out that albinism can also result from the failure of neural crest derived and optic cup derived melanocytes to reach their destinations in epidermis and retina. The mutant Microphthalmia $(m i)$ seems to be an example of this.

\section{Agouti}

This locus is concerned with the regional distribution of dark and light pigments within individual hairs and in the coat as a whole. The same melanocyte can produce both types of pigment, as shown by the formation of a yellow (agouti) band in an otherwise dark hair. In fact there is evidence that both types of pigment granule (eumelanosomes and phaeomelanosomes) can be present at the same time in a melanocyte (SAKurai et al., I975). Action at the Agouti locus is via the tissue (follicular) environment (BILLINGHam and SILVERS, I960) and should be primarily concerned with the regulation of the synthesis of the cysteinyldopas (fig. I). However, work is needed to provide a more precise metabolic meaning for the gene action at this locus.

\section{Extension}

This locus is also involved in phaeomelanin production, since different alleles extend or restrict the amount of yellow pigment in the coat. Homozygotes for the bottom recessive allele, $e$ have a yellow coat similar to that of heterozygotes for $A^{y}$. However, it tends to be rather sooty (with admixture of eumelanin) in young $e e$ mice, more so than in $A^{y}$. Moreover, $A^{y}+e e$ mice resemble $e e$ in coat colour.

Gene action of $e$ is within the melanocyte, but it seems that phaeomelanin can only be produced in the environment of the hair follicle (LAMOREUX and MAYER, I975). Action of the allele for partial extension of yellow, which gives a variegated phenotype, is exactly what would be expected if there were separate clones of black-forming and yellow-forming melanocytes, with random inactivation of alleles for production of one or other colour (SEARLE, I968). Thus there are no quantitatively intermediate alleles of the type found in the albino series.

The marked difference in the effects and mode of action of the $\mathrm{E}$ locus with respect to the agouti locus makes it uncertain whether the nature and formation of the phaeomelanins observed in the extension series correspond to those of the apparently similar pigment in the agouti series. 


\section{Brown}

The best known allele is recessive brown (b) which acts on eumelanin pigmentation only, but a dominant allele $\left(B^{l t}\right)$ which lightens the coat, especially the underfur, has been found in the mouse. Melanosomes of brown mice are rounded rather than ovoid, but also have rather a disordered internal structure, with coarsely granular melanin (MOYER, r963). This gene is known to act within the melanocyte, but it is not yet clear whether the altered structure of mutant granules result from formation of an abnormal type of melanin or not. Indeed, little is known on the chemistry of the brown melanins.

\section{Pink-eyed dilution}

Alleles at this locus tend to affect eumelanin pigmentation much more than phaeomelanin. In $p p$ mice, eumelanosomes become very abnormal, being small and shred-like with an irregular matrix and a marked reduction in cross-linking of fibres (MOYER, I963), while retinal pigment granules are not formed. Phaeomelanosomes, however, have a normal structure. Action of the gene is again within the melanocyte (SILVERS, I957) and one could postulate that it is concerned with the final stages in formation of the eumelanosome.

\section{Dilute}

In recessive dilution (and in its mimic leaden in the mouse) the epidermal (but not the retinal) melanocyte changes its shape, from nucleofugal to nucleopetal (MARKERT and Silvers, I956), and its pigment granules are deposited in clumps, whether eumelanic or phaeomelanic. Thus this interesting gene must help to determine the morphology of the epidermal pigment cell derived from the neural crest, rather than any stages in melanogenesis. Homozygotes for another allele, dilute lethal $\left(d^{l}\right)$, suffer from convulsions (SEARLE, I952) associated with extensive demyelination of certain tracts of nerve fibres (KELTON and RAUCH, I962). Biochemical defects associated with phenylalanine have also been reported in these mutants, but it seems likely from later work that these were secondary results of the disease process (WOOLF, I970). It should be pointed out that although diluting mutants which clump pigment granules in species other than the mouse are regarded as homologous with dilute $(d)$ in the mouse, homology with the mimic gene leaden $(l n)$ is another possibility.

\section{Sex-linked yellow}

Although it is not a member of a well established allelic series, one other locus should be mentioned because it may well be directly involved in melanin formation. This is sex-linked yellow, known only in the cat (orange, $O$ ) and the Syrian hamster 
(tortoiseshell, To) (see SEARLE, I968). There is good reason to believe that this locus is not homologous with that for extension of yellow $(e)$ because $(i)$ the Syrian hamster appears to have both loci and (ii) this locus is on the $\mathrm{X}$-chromosome, which OHNO (I967) suggests has been conserved in mammalian evolution, while the extension locus is autosomal. The orange allele at the sex-linked Yellow locus in the cat behaves like recessive yellow in giving full extension of phaeomelanin pigments, so that the efiect of $A$ gouti alleles cannot show up. The wild type allele allows normal expression of $A$ gouti etc., while females heterozygous for orange show the well-known tortoiseshell pattern. This results from the presence of clones of yellow and non-yellow melanocytes, arising from random inactivation of one or other X-chromosome (LYON, I96I). Thus this gene exists in only two alternative forms and may well be regulatory in nature. Possibly it is the regulator gene for the structural extension locus. If so, it is strange that so few species are known to possess it.

\section{Concluding remarks}

Of the six main allelic series concerned with mammalian coat coloration, three, namely $B, D$ and $P$, seem to affect mainly the differentiation and the fine structure of melanosomes, while $A, C$ and $E$ are likely to control the basic enzymic steps of melanogenesis. Mutations leading to albinism even in the presence of pigment cells occur at the $C$ locus which therefore should contain the structural gene for tyrosinase, the key enzyme of melanogenesis. It is generally agreed that genes at the $A$ and $E$ loci are involved in the control of phaeomelanin biosynthesis but details of the mechanism of their action are needed as apparently they allow the formation of the same type of pigment in two very different ways. In the A gouti series, the biochemical message favouring the formation of phaeomelanins, presumably via cysteinyldopas, comes from outside the melanocyte and its action is determined by the $A$ gouti allele present, by regional influences and by such factors as MSH. In the extension series, gene action is autonomous and uninfluenced by external factors. Therefore it seems probable that these genes control distinct enzyme systems, the possible nature of which remains indefinite because of lack of experimental evidence regarding primarily $(i)$ the nature and chemical identity of the phaeomelanins observed in the Agouti and extension series, and (ii) the actual metabolic pathway leading to the formation of the cysteinyldopas.

Rę̧u pour publication en avril 1978 .

\section{Résumé}

Localisations biochimiques de l'action des gènes qui contrôlent la mélanogenèse des Mammitères

L'information concernant les bases biochimiques et génétiques de la couleur du pelage est passée en revue. Alors que l'on peut considérer que les pigments eumélaniques sombres forment un groupe assez homogène, les phaeomélanines plus claires sont plus diverses, comprenant des trichochromes (de faible poids moléculaire) aussi bien que des composés sulfurés plus complexes. Cependant à la fois les eumélanines et les phaeomélanines proviennent d'une voie métabolique commune avec, comme intermédiaire clé, la dopaquinone. Six principales séries allélomorphiques qui contrôlent la couleur du pelage ont été mises en évidence chez les Mammifères. De ces six séries les séries Brun $(B)$, Dilution $(D)$ et Dilution à coil rose $(P)$ affectent, semble-t-il, principale- 
ment la différenciation et la structure fine des mélanosomes (ainsi que celle des mélanocytes pour 1a Dilution) alors que les gènes des séries Agouti $(A)$, Albinos $(C)$ et Extension $(E)$ semblent surtout contrôler les voies enzymatiques de la mélanogenèse. Ce que l'on sait de la biochimie suggère que, pour la formation de l'eumélanine au moins, un de ces enzymes est probablement la tyrosinase, contrôlée par le locus Albinos. Pour la formation des phaeomélanines il faut au moins deux enzymes, donc deux gènes. Les loci Agouti et Extension semblent tous les deux impliqués dans cette production de phaeomélanine, le premier à travers le tissu environnant et le second à l'intérieur du mélanocyte. De nouvelles études sont encore nécessaires pour déterminer quels enzymes sont impliqués et les types exacts de phaeomélanine produite.

\section{References}

Agrup G., Falck B., Kennedy B. M., Rorsman H., Rosengren E., I975. Formation of cysteinyldopa from glutathionedopa in melanoma. Acta Dermato-veneveol. (Stockholm), 55, I-3.

Biorklund A., Falck B., Jacobson S., Rorsman H., Rosengren A. M. and Rosengren F., 1972. Cysteinyldopa in human malignant melanoma. Acta Dermato-venereol. (Stockholm), 52, 357-360.

Bilitingham R. E. and Silvers W. K., r96o. The melanocytes of mammals. Quart. Rev. Biol. $35,1-40$.

Fatruorusso E., Minale L., Cimino G., De Steifano S., and Nicolaus R. A., ig69. Struttura e biogenesi delle feomelanine. IX. Feomelanine biosintetiche, Gazz. Chim. Ital., 99, 969-992.

Fatrorusso E., Minale L. and Sodano G., i97o. Feomelanine da nuove fonti naturali. Gazz. Chim. Ital., 100, 452 .

Foster M., 1965. Mammalian pigment genetics. Adv. Genetics, 13, 311-339.

HEARING V. J., I973. Tyrosinase activity in subcellular fractions of black and albino mice. Nature New Biol., 245, 8I-83.

Jimbow K., Quevedo W. D., Fitzpatrick T. B. and Szabo G., I976. Some aspects of melanin biology: 1950-1975, J. Invest. Dermatol, 67, 72-89.

KeLton D. E. and RAUCH H., 1962. Myelination and myelin degeneration in the central nervous system of dilute-lethal mice. Exp. Neurol., 6, 252-26z.

LAMOREUX M. L. and MAYeR T. C., I975. Site of gene action in the development of hair pigment in recessive yellow $(e / e)$ mice. Devel. Biol., 46, I60-I 66.

LyON M. F., I96r. Gene action in the X-chromosome of the mouse. Nature, 190, 372-373.

MARKERT C. L. and SiLvers W. K., I956, The effects of genotype and cell environment on melanoblast differentiation in the house mouse. Genetics, 41, 429-450.

Moyer F. H., I966. Genetic variations in the fine structure and ontogeny of mouse melanin granules. Amer. Zool., 6, 43-66.

MOYER F. H., I 963 . Genetic effects of melanosome fine structure and ontogeny in normal and malignant cells. Ann. N.Y. Acad. Sci., 100, 584-606.

Nicolaus R. A., I968. Melanins, Hermann, Paris.

OHNo S. Sex-chromosomes and sex-linked genes (Springer-Verlag, Berlin, 1967).

Prota G., 1972. Structure and Biogenesis of phaeomelanins. In V. RILEY " Pigmentation, its genesis and biologic control ". Appleton-Century-Crafts, New York, 6I5-630.

Prota G. and Thomson R. H., 1976. Melanin pigmentation in mammals, Endeavour, 35, 32-38.

SAKURAI T., OChIAI H. and TAKEUCHI T., 1975. Ultrastructural change of melanosomes associated with agouti pattern formation in mouse hair. Devel. Biol., 47, 466-47I.

SEARlE A. G., I968. Comparative Genetics of Coat Colour in Mammals. Logos/Academic, London.

SEARLE A. G., I952. A lethal allele of dilute in the mouse. Heredity, 6, 395-40I.

SILVERS W. K., 1957. Melanoblast differentiation secured from different mouse genotypes after transplantation to adult mouse spleen or to chick embryo coelom. J. Exp. Zool., 135, 2z1-234.

Thomson A. H., 1974. The pigments of reddish hair and feathers. Angew. Chem. Internat. Edit., 13, 305-312.

WoOlF L. I., JAKUboric A., WoolF F., and BORy P., I97o. Metabolism of phenylalanine in mice homozygous for the gene "dilute lethal ".Biochem. J., 119, 895-903. 